\title{
A eficácia da função social na propriedade pública*
}

\section{The efficacy of "social function" in public real state}

Roberto Freitas Filho ${ }^{1}$ Flora Regina Camargos Pereira ${ }^{2}$
Recebido em: 05/10/2016. Aprovado em: 08/11/2016. Advogado, possui graduação em Direito pela Universidade Católica de Santos (1993), mestrado em Direito pela Universidade de São Paulo (2002), doutorado em Direito pela Universidade de São Paulo (2006) e Pós-Doutorado pela Universidade de Wisconsin - Madison - EUA (2006). Atualmente é coordenador do Curso de Direito do Centro Universitário de Brasília - UniCEUB e Professor do Programa de Mestrado do Instituto Brasiliense de Direito Público - IDP. E-mail: freitasfilho. roberto@gmail.com.

2 Assessora Jurídica da Diretoria de Patrimônio Imobiliário e Meio Ambiente do Exército Brasileiro, possui graduação pela Universidade Federal de Juiz de Fora (2005), pós-graduação em direito privado pela Universidade Cândido Mendes (2006). Atualmente é mestranda em Direito Constitucional pelo Instituto Brasiliense de Direito Público. E-mail: floracamargos@yahoo.com.br.

\section{Resumo}

O direito de propriedade é inerentemente ligado à sua função social. Consagrada no ordenamento jurídico brasileiro, a função social condiciona o exercício do direito de propriedade. Quando se fala em propriedade privada, a aplicação da função social é mais bem aceita. Porém, no que se refere à propriedade pública há grande controvérsia sobre a aplicação. Assim, o presente artigo se propõe em primeiro lugar a determinar qual o espaço ocupado no ordenamento jurídico brasileiro pela função social, para na sequência apresentar suas formas de aplicação e, por fim, perquirir a respeito de sua eficácia quando se trata dos vários tipos de propriedades públicas. Ressalta-se que este estudo se foca apenas nas propriedades públicas imóveis. Ao final, a conclusão confirma que o modelo adotado pelo Estado brasileiro exige que se dê a maior abrangência possível à aplicação da função social, mesmo quando se trate de propriedades públicas. A função social deve ser aplicada aos imóveis públicos, na medida do possível, para, com isso, ajudar a garantir a consecução dos fins almejados pelo Estado Democrático de Direito brasileiro.

Palavras-chave: Propriedade. Função social. Bens públicos. Eficácia.

\begin{abstract}
The property right is inherently linked to its social function. Enshrined in the Brazilian legal system, the social function limits the exercise of property rights. When it comes to private property, the application of social function is more accepted. However, with regard to public property there is great controversy over the application. Thus, this article aims primarily to determine the space occupied in the Brazilian legal system by the social function and its application forms and finally to assert about its effectiveness when it comes to the various types of public properties. It is noteworthy that this study focuses only on public real estate properties. At the end, the conclusion confirms that the model adopted by the Brazilian law requires maximization of the application of social function, even in the case of public real estate properties. The social function should be applied to public buildings, as far as possible, to thereby help ensure the achievement of the objectives pursued by the democratic state of Brazilian law.
\end{abstract}

Keywords: Property. Social function. Public real estate property. Efficiency. 


\section{Introdução}

$\mathrm{Na}$ atual estrutura jurídica brasileira não há como referir-se ao direito de propriedade sem pressupor que ele atende a uma função social a ser respeitada em seu exercício. Tanto que o ordenamento jurídico brasileiro consagra a função social na carta suprema em vários pontos, assim como na legislação infraconstitucional.

Antes de qualquer análise mais aprofundada, deve-se perquirir como o cumprimento da função social ingressa na ordem jurídica e como será aquilatada sua aplicação na prática.

Superada essa alocação inicial, outras indagações hão de ser verificadas. Quando se pergunta sobre a abrangência da aplicação da função social da propriedade há um certo consenso no que tange a sua incidência sobre a propriedade particular. Contudo, o mesmo não ocorre quando se fala das propriedades públicas.

Considerando que os bens públicos já são naturalmente vocacionados ao atendimento das necessidades da sociedade e da coletividade como um todo, surge a dúvida de como conciliar a característica natural dos bens públicos com a aplicação da função social. Para isso, será importante verificar onde se encaixa a função social da propriedade pública quanto à justiça, validade e eficácia. ${ }^{3}$

Nesse intento, será necessário diferenciar as diversas categorias de bens públicos para, a partir disso, averiguar se ao menos com relação a uma ou algumas delas é possível verificar-se a eficácia da aplicação da norma da função social, ou seja, deverá ser respondida a seguinte questão: a norma da função social possui eficácia com relação aos bens públicos?

\section{A função social da propriedade}

Apesar de não ser pretensão deste trabalho proceder a uma digressão histórica detalhada do surgimento da função social da propriedade ${ }^{4}$, necessário se faz tocar ao menos em alguns pontos-chave que deram origem à ideia que a função social encerra.

A função social tem sua gênese ligada à concep-

A referência para tanto será BOBBIO, Norberto. Teoria da norma jurídica. 4. ed. Rio de Janeiro: Forense, 2006.

4 Para maior aprofundamento sobre o histórico do tema remete-se o leitor ao trabalho de Olindo Herculano de Menezes, disponível em: <http://repositorio.unb.br/bitstream/10482/4076/1/2009_OlindoHerculanodeMenezes. pdf $>$. ção cristã da propriedade, sobretudo na doutrina social do catolicismo: Já é possível identificar um embrião da função social na Suma Teológica de São Tomás de Aquino, obra escrita no Século XIII e tida como um dos pilares da dogmática católica. ${ }^{5}$

Também podem ser identificados indícios da ideia de função social em Rousseau que, em 1762 anotava os seguintes termos:

Em geral, para outorgar, sobre um terreno qualquer, o direito de primeiro ocupante, são necessárias as seguintes condições: primeiramente, que o terreno não seja ainda habitado por ninguém; em segundo lugar, que só se ocupe a quantidade de que se precisa para subsistir; em terceiro lugar, que se tome posse, não por uma vã cerimônia, mas pelo trabalho e cultura, único sinal de propriedade que, na falta de títulos legais, deve ser respeitado por outros[...]De qualquer maneira que se faça essa aquisição, o direito que cada particular tem sobre o próprio terreno é sempre subordinado ao direito que a comunidade tem sobre todos, sem o que não haveria nem solidez no vínculo social, nem força real no exercício da soberania. ${ }^{6}$

Todavia, apesar de ser um conceito assaz antigo, foi na mudança do Estado Liberal para o Estado Social que a função social ganhou força. Segundo Lôbo ${ }^{7}$, o Estado social, no plano de direito, é todo aquele que tem incluída na Constituição a regulamentação da ordem econômica e social. Além da limitação ao poder político, limita-se o poder econômico e projeta-se para além dos indivíduos a tutela dos direitos, incluindo o trabalho, a educação, a cultura, a saúde, a seguridade social, o meio ambiente, todos como inegáveis reflexos nas dimensões materiais do Direito Civil.

Pode-se afirmar, em resumo, que a migração do Estado Liberal para o Social, no início do século XX, proporcionou a busca de uma igualdade material entre

5 Em período posterior a Igreja Católica mantém sua influência no assunto. DI PIETRO, Maria Sylvia Zanella. Direito administrativo. 17. ed. São Paulo: Atlas, 2004. p. 122, afirma que as encíclicas Mater et Magistra do Papa João XXIII, de 1961 e Populorum Progressio, do Papa Paulo VI, de 1967, atribuem a função social à propriedade, na medida que colocam esta última como instrumento para a criação de bens necessários à subsistência de toda humanidade.

6 ROUSSEAU, Jean- Jacques. Do contrato social: princípios de direito político. 2. ed. São Paulo: Revista dos Tribunais, 2008. p. 37; 39.

7 LÔBO, Paulo Luiz Netto. Constitucionalização do Direito civil. In: FIUZA, Cesar; SÁ, Maria de Fátima Freire; NAVES, Bruno Torquato de Oliveira (Coord.). Direito civil: constitucionalização. Belo Horizonte: Del Rey, 2003. p. 102-197. 
os indivíduos para a construção de uma sociedade mais equânime com a introdução de direitos sociais, culturais e econômicos. Se antes o absenteísmo estatal era a regra, no Estado social a igualdade almejada exige a atuação estatal, sobretudo com o aumento da intervenção nas relações contratuais e na imposição de obrigações positivas ao Estado.

Segundo Streck $^{8}$ a necessidade de intervenção estatal decorreu de várias incongruências do modelo liberal, sendo as mais relevantes: a revolução industrial, a primeira guerra mundial, a crise de 1929, a segunda guerra mundial, as crises econômicas cíclicas, a insustentabilidade de um ideal de força regulatória livre do próprio mercado e a alteração paradigmática das liberdades negativas para as liberdades positivas e sociais.

O mesmo autor ainda enumera fatores que contribuíram para a transição do Estado Liberal para o Social: a acentuação das diferenças sociais decorrentes das crises, a preocupação crescente com o bem-estar social, inspirada em doutrinas socialistas, entre outras.

Esse cenário serviu de pano de fundo para a consolidação da indispensabilidade da função social. A função social da propriedade teve destaque em documentos jurídicos marcantes na transição liberal-social, dentre os quais se destacam a Constituição alemã de Weimar de 1919 e a Constituição Mexicana de 1917.

Herrera ${ }^{9}$ afirma que o artigo 27 pode ser considerado como o mais importante da Constituição Mexicana de 1917 em razão da estrutura agrária do México. Ele enuncia o princípio da limitação da propriedade privada pelo interesse público, regulando os princípios da expropriação e da reforma agrária. Desse modo, o citado artigo claramente resguarda o interesse social da propriedade, isto é, prevê sua função social:

Art. 27. A propriedade da terra e das águas dentro dos limites do território nacional pertence originariamente à Nação, a qual teve e tem o direito de transmitir o domínio delas aos particulares, constituindo assim a propriedade privada.

A expropriação só pode se dar no interesse público e mediante indenização.A Nação terá, a todo tempo, o direito de impor à propriedade privada as determinações ditadas pelo interes-

8 STRECK, Lenio Luiz; MORAIS, José Luis Bolzan de. Ciência política e teoria do Estado. 7. ed. Porto Alegre Livraria do Advogado, 2010. p. 70;74.

9 HERRERA, Carlos Miguel. Estado, constituição e direitos sociais. Revista da Faculdade de Direito da Universidade de São Paulo, São Paulo, v. 102, p. 371-395, jan./dez., 2007. se público, assim como o de regular o aproveitamento de todos os recursos naturais suscetíveis de apropriação, com o fim de realizar uma distribuição eqüitativa da riqueza pública e para cuidar de sua conservação, alcançar um desenvolvimento equilibrado do país e melhorar as condições de vida da população rural e urbana.

Com esse objetivo devem ser tomadas as medidas necessárias para ordenar os assentamentos humanos e estabelecer disposições adequadas, usos, reservas e destinos de terra, água e florestas, a fim de realizar obras públicas e de planejamento e regulação da fundação, conservação, melhoria e crescimento de centros populacionais; para preservar e restaurar o equilíbrio ecológico; o fracionamento dos latifúndios; para fornecer, nos termos da lei de regulamentação, a organização e exploração coletiva dos ejidos ${ }^{10}$ e comunidades; para a promoção da agricultura, pecuária, silvicultura e das outras actividades económicas nas zonas rurais, e para evitar a destruição de elementos naturais e os danos a propriedade pode sofrer em detrimento da sociedade. $^{11}$

A Constituição Alemã de Weimar de 1919 também previu a função social da propriedade, talvez de modo um pouco mais tímido que a Mexicana de 1917, mas ainda assim consagrando a importância do interesse

10 Para os mexicanos, o ejido é uma propriedade rural de uso coletivo, terra de uso comum ou cooperativo.

11 Tradução livre: "Artículo 27. La propiedad de las tierras y aguas comprendidas dentro de los límites del territorio nacional, corresponde originariamente a la Nación, la cual ha tenido y tiene el derecho de transmitir el dominio de ellas a los particulares, constituyendo la propiedad privada. Las expropiaciones sólo podrán hacerse por causa de utilidad pública y mediante indemnización. La nación tendrá en todo tiempo el derecho de imponer a la propiedad privada las modalidades que dicte el interés público, así como el de regular, en beneficio social, el aprovechamiento de los elementos naturales susceptibles de apropiación, con objeto de hacer una distribución equitativa de la riqueza pública, cuidar de su conservación, lograr el desarrollo equilibrado del país y el mejoramiento de las condiciones de vida de la población rural y urbana. En consecuencia, se dictarán las medidas necesarias para ordenar los asentamientos humanos y establecer adecuadas provisiones, usos, reservas y destinos de tierras, aguas y bosques, a efecto de ejecutar obras públicas y de planear y regular la fundación, conservación, mejoramiento y crecimiento de los centros de población; para preservar y restaurar el equilibrio ecológico; para el fraccionamiento de los latifundios; para disponer, en los términos de la ley reglamentaria, la organización y explotación colectiva de los ejidos y comunidades; para el desarrollo de la pequeña propiedad rural; para el fomento de la agricultura, de la ganadería, de la silvicultura y de las demás actividades económicas en el medio rural, y para evitar la destrucción de los elementos naturales y los daños que la propiedad pueda sufrir en perjuicio de la sociedad. 
coletivo que recai sobre o exercício do direito de proprie-

dade. Em seu artigo 153, dita a Carta de Weimar:

Artigo 153 - A propriedade é garantida pela Constituição. Seu conteúdo e suas limitações resultam das leis. A expropriação somente pode ser realizada para o bem público e numa base legal. Far-se-á sempre mediante adequada indenização, a menos que uma lei do Reich ${ }^{12}$ disponha em contrário. Caso haja litígio o valor da indenização poderá ser discutido nos tribunais ordinários, salvo se as leis do Reich dispuserem diversamente. A expropriação pelo Reich sobre os Estados, municípios e organizações sem fins lucrativos só pode ter lugar mediante compensação. A propriedade implica obrigações. Seu uso deve ser ao mesmo tempo um serviço no mais alto interesse público. ${ }^{13}$

Pouco antes da edição das duas constituições supracitadas, e no mesmo sentido, há que se citar o pensamento de Léon Duguit ${ }^{14}$, precursor da ideia de função social. O autor francês desenvolveu, em 1912, a ideia da função social inspirado nas lições sociológicas desenvolvidas por Comte e Durkheim ${ }^{15}$. Duguit entendia que todo indivíduo tem uma função a cumprir na sociedade e esse seria o fundamento, a regra de direito que a todos se impõe. Nessa linha de pensamento, a propriedade deve ser exercida considerando a função social do indivíduo que a detém. Assim, a propriedade teria dupla função: a satisfação das necessidades individuais do proprietário e o dever de empregar sua propriedade também na satisfação das necessidades da coletividade. Segundo Duguit:

Toda pessoa tem o dever de exercer na socie-

12 Palavra alemã que no contexto remonta à ideia de Nação.

13 Tradução livre de: "Artikel Das Eigentum wird von der Verfassung gewährleistet. Sein Inhalt und seine Schranken ergeben sich aus denGesetzen. Eine Enteignung kann nur zum Wohle der Allgemeinheit und auf gesetzlicher Grundlage vorgenommen werden. Sieerfolgt gegen angemessene Entschädigung, soweit nicht ein Reichsgesetz etwas anderes bestimmt. Wegen der Höhe der Entschädigung ist im Streitfalle der Rechtsweg bei den ordentlichen Gerichten offen zu halten, soweit Reichsgesetze nichts anderesbestimmen. Enteignung durch das Reich gegenüber Ländern, Gemeinden und gemeinnützigen Verbänden kann nur gegen Entschädigung erfolgen. Eigentum verpflichtet. Sein Gebrauch soll zugleich Dienst sein für das Gemeine Beste;"

14 DUGUIT, Leon. Les transformations générales du droit privé depuis le code Napoléon. 19. ed. Paris: Librairie Félix Alcan, 1920.

15 Comte e Durkheim, em apertada síntese, entendem que a sociedade deve ser analisada de forma objetiva. Sobretudo em Durkheim é possível identificar que a sociedade é entendida como um todo orgânico a semelhança do corpo humano, onde cada indivíduo tem sua função para o funcionamento do todo. dade uma determinada função em proporção direta ao lugar que ocupa. No entanto, o titular da riqueza na sociedade pode realizar uma determinada tarefa que só ele pode executar. Só ele pode aumentar a riqueza geral, garantir a satisfação das necessidades gerais de capital argumentando que detém. É, portanto, socialmente necessário para realizar essa tarefa e socialmente protegido do que dele se faz, e na medida em que ele realiza. A propriedade não é um direito subjetivo do proprietário; é a função social do titular da riqueza. ${ }^{16}$

A contribuição de Duguit com relação à função social da propriedade é inegável. Contudo, cabe uma crítica ao seu pensamento. Duguit considerou que a propriedade não é um direito, o que não parece uma premissa pertinente. Consoante Rocha:

A crítica que pode ser feita ao pensamento de León Duguit reside na premissa do raciocínio por ele desenvolvido de não ser a propriedade um direito, mas uma riqueza passível de proteção pelo direito objetivo violado por terceiros, quando, na verdade, não se duvida que a propriedade constitua um direito subjetivo. Não obstante o equívoco da premissa, a lição de Duguit contribuiu para que Constituições posteriores incluíssem em seus textos a função social da propriedade. ${ }^{17}$

Após esta rápida digressão histórica, cabe adentrar na evolução da função social no ordenamento jurídico pátrio, o que se fará a seguir.

\section{A função social da propriedade no ordena- mento brasileiro}

A primeira vez que a função social da propriedade aparece no ordenamento jurídico brasileiro é na Constituição de 1934 que, inspirada na Constituição Alemã de Weimar, inaugura o Estado social em nosso País. A função social aflora, ainda que de modo indireto, no art. 113, o qual dispunha em seu item 17:

16 DUGUIT, Leon. Les transformations générales du droit privé depuis le code Napoléon. 19. ed. Paris: Librairie Félix Alcan, 1920. p. 158. Tradução livre de: "Tout individu a l'obligation d'accomplir dans la société une certaine fonction en raison directe de la place qu'il y occupe. Or, le détenteur de la richesse, peut accomplir dans la société une certaine besogne que lui seul peut accomplir. Seul il peut augmenter la richesse générale, assurer la satisfaction de besoins généraux en faisant valoir le capital qu'il détient. Il est donc obligé socialement d'accomplir cette besogne e il ne sera protégé socialement que s'il l'accomplit et dans la mesure où il l'accomplit. La propriété n'est plus le droit subjectif du propriétaire; elle est la fonction sociale du détenteur de la richesse."

17 ROCHA. Silvio Luis Ferreira. Função social da propriedade pública. São Paulo: Malheiros, 2005. p. 71. 
É garantido o direito de propriedade, que não poderá ser exercido contra o interesse social ou coletivo, na forma que a lei de terminar. A desapropriação por necessidade ou utilidade pública far-se-á nos termos da lei, mediante prévia e justa indenização. Em caso de perigo iminente, como guerra ou comoção intestina, poderão as autoridades competentes usar da propriedade particular até onde o bem público o exija, ressalvado o direito à indenização ulterior. ${ }^{18}$

A Constituição de $1937^{19}$, conhecida como Constituição Polaca, não repetiu a disposição da carta antecedente, apenas garantiu o direito à propriedade.

Somente na Constituição de $1946^{20}$ a função social da propriedade foi restabelecida. Num contexto marcado em âmbito externo pelo fim da segunda guerra e em âmbito interno pela redemocratização, com o fim do Estado Novo de Getúlio Vargas, a função social da propriedade ganhou força. O art. 141, inserto no título que tratava da Ordem Econômica e Social, assim rezava : "O uso da propriedade será condicionado ao bem-estar social. A lei poderá, com observância do disposto no art. 141, $\$ 16$, promover a justa distribuição da propriedade, com igual oportunidade para todos".

$\mathrm{Na}$ Constituição de $1967^{21}$ a função social foi mantida entre os princípios da ordem econômica: "A ordem econômica tem por fim realizar a justiça social, com base nos seguintes princípios: [...] III - função social da propriedade."

A Emenda Constitucional de $1969^{22}$ manteve a função social nos mesmos termos da Constituição de 1967, mudando apenas o número do artigo, que passou a ser o art. 160, inciso III, com idêntica redação.

18 BRASIL. Constituição (1934). Constituição da República dos Estados Unidos do Brasil. Disponível em: <http://www. planalto.gov.br/ccivil_03/constituicao/constituicao34. htm>. Acesso em: 17 set. 2016.

19 BRASIL. Constituição (1937). Constituição da República dos Estados Unidos do Brasil. Disponível em: <http://www. planalto.gov.br/ccivil 03/constituicao/constituicao37. htm>. Acesso em: 17 set. 2016.

20 BRASIL. Constituição (1946). Constituição da República dos Estados Unidos do Brasil. Disponível em: <http://www. planalto.gov.br/ccivil_03/Constituicao/Constituicao46. htm>. Acesso em: 17 set. 2016.

21 BRASIL. Constituição (1988). Constituição da República Federativa do Brasil. Disponível em: <http://www.planalto.gov.br/ccivil_03/Constituicao/Constituicao.htm $>$. Acesso em: 17 set. 2016.

22 BRASIL. Emenda constitucional n. 1, de 17 de outubro de 1969. Disponível em: <http://www.planalto.gov.br/ccivil_03/Constituicao/Emendas/Emc_anterior1988/emc0169.htm>. Acesso em: 17 set. 2016.
A Constituição de $1988^{23}$, Constituição Cidadã, consolidou a relevância da função social. $\mathrm{Na}$ atual Constituição, ela é encontrada não só no título da Ordem econômica e Social, mas em outras variadas partes do texto constitucional. Isto se explica, para Bonavides porque "a constituição de 1988 é basicamente, em muitas de suas dimensões essenciais, uma Constituição do Estado social" $^{24}$.

A função social, consoante já dito, ganha um viés mais abrangente na Constituição de 1988 e aparece em vários pontos de seu texto. A Carta Política atual continua a tradição das anteriores ao inserir a função social da propriedade no título da Ordem Econômica e Financeira, porém, de forma mais abrangente, conforme se vê nos artigos $170,182,184,185$ e $186 .{ }^{25}$

Apesar de manter a função social no título da Ordem Econômica e Financeira, a Constituição de 1988 inova, pois a primeira aparição da função social em texto

23 BRASIL. Constituição (1988). Constituição da República Federativa do Brasil. Disponível em: <http://www.planalto.gov.br/ccivil_03/Constituicao/Constituicao.htm $>$. Acesso em: 17 set. 2016.

24 BONAVIDES, Paulo. Curso de direito constitucional. 25. ed. São Paulo: Malheiros, 2010. p. 371.

25 Art. 170. A ordem econômica, fundada na valorização do trabalho humano e na livre iniciativa, tem por fim assegurar a todos existência digna, conforme os ditames da justiça social, observados os seguintes princípios: [...] III - função social da propriedade;[...] Art. 182. A política de desenvolvimento urbano, executada pelo Poder Público municipal, conforme diretrizes gerais fixadas em lei, tem por objetivo ordenar o pleno desenvolvimento das funções sociais da cidade e garantir o bem- estar de seus habitantes. [...] $\$ 2^{\circ}$ A propriedade urbana cumpre sua função social quando atende às exigências fundamentais de ordenação da cidade expressas no plano diretor. [...] Art. 184. Compete à União desapropriar por interesse social, para fins de reforma agrária, o imóvel rural que não esteja cumprindo sua função social, mediante prévia e justa indenização em títulos da dívida agrária, com cláusula de preservação do valor real, resgatáveis no prazo de até vinte anos, a partir do segundo ano de sua emissão, e cuja utilização será definida em lei. [...] Art. 185. São insuscetíveis de desapropriação para fins de reforma agrária: I - a pequena e média propriedade rural, assim definida em lei, desde que seu proprietário não possua outra; II - a propriedade produtiva. Parágrafo único. A lei garantirá tratamento especial à propriedade produtiva e fixará normas para o cumprimento dos requisitos relativos a sua função social. Art. 186. A função social é cumprida quando a propriedade rural atende, simultaneamente, segundo critérios e graus de exigência estabelecidos em lei, aos seguintes requisitos: I - aproveitamento racional e adequado; II - utilização adequada dos recursos naturais disponíveis e preservação do meio ambiente; III - observância das disposições que regulam as relações de trabalho; IV - exploração que favoreça o bem-estar dos proprietários e dos trabalhadores. 
ocorre no art. $5^{\circ}$, integrante do título que trata dos Direitos e Garantias fundamentais. ${ }^{26}$

Dessa nova inserção topográfica da função social da propriedade é que emerge a discussão proposta pelo presente trabalho. A evolução do pensamento constitucional valoriza cada vez mais a proteção dos direitos fundamentais frente ao Estado, assim como nas inter-relações entre os particulares. Nesse contexto, a migração topográfica da função social para o título relativo aos direitos fundamentais sinaliza que sua aplicação deve ocorrer não só no contexto econômico (consoante se imaginava nas constituições anteriores) das relações entre particulares relativas à propriedade privada dos indivíduos, mas também nas relações que envolvam o poder público.

Nesse ponto, Sarlet ${ }^{27}$ compara a Constituição brasileira vigente com as Constituições alemã e portuguesa e afirma:

Ao art. $5^{\circ}, \$ 1^{\circ}$, da constituição de 1988 é possível atribuir, sem sombra de dúvidas, o mesmo sentido outorgado ao art.18/1 da Constituição da República Portuguesa a ao art. $1^{\circ}$, inc. III, da Lei Fundamental da Alemanha, o que em última análise significa - de acordo com a lição de Jorge Miranda - que cada ato (qualquer ato) dos poderes públicos deve tomar os direitos fundamentais como "baliza e referencial".

Assim, a aplicação deve ser efetuada da forma mais abrangente possível, posto ser esta a forma de tratamento a ser dispensada aos direitos fundamentais. Desta feita, a nova visão inaugurada pela Constituição Cidadã leva a crer que a função social também deve ser aplicada com relação a outras propriedades que não sejam as privadas, isto é, aplicar-se-ia também às propriedades públicas.

\section{Natureza da função social da propriedade}

A partir da CF/88 se fez necessário determinar a que título a norma da função social foi recebida pelo ordenamento jurídico pátrio. Consoante os ensinamentos de $\mathrm{Alexy}^{28}$, as normas jurídicas de direitos fundamentais,

$26 \quad$ Art. $5^{\circ}$ Todos são iguais perante a lei, sem distinção de qualquer natureza, garantindo-se aos brasileiros e aos estrangeiros residentes no País a inviolabilidade do direito à vida, à liberdade, à igualdade, à segurança e à propriedade, nos termos seguintes: [...] XXIII - a propriedade atenderá a sua função social.

27 SARLET, Ingo Wolfgang. A eficácia dos direitos fundamentais. 12. ed. Porto Alegre: Livraria do Advogado, 2015. p. 383. quando classificadas de acordo com sua estrutura, repartem-se em princípios e regras, cada qual com seu papel específico. $^{29}$

Dworkin $^{30}$, em sua obra Levando os Direitos a sério, comunga das ideias de Alexy ao afirmar a divisão das normas em regras e princípios e as diferenças entre ambos. $^{31}$

Considerando essas ideias de ícones do pensamento jurídico, pode-se inferir que a função social da

29 Afirma o autor: "O ponto decisivo na distinção entre regras e princípios é que princípios são normas que ordenam que algo seja realizado na maior medida possível dentro das possibilidades jurídicas e fáticas existentes. Princípios são, por conseguinte, mandamentos de otimização, que são caracterizados por poderem ser satisfeitos em graus variados e pelo fato e de que a medida devida de sua satisfação não depende somente das possibilidades fáticas, mas também das possibilidades jurídicas. $\mathrm{O}$ âmbito das possibilidades jurídicas é determinado pelos princípios e regras colidentes. Já as regras são sempre ou satisfeitas ou não satisfeitas. Se uma regra vale, então, deve se fazer exatamente aquilo que ela exige; nem mais, nem menos. Regras contêm, portanto, determinações no âmbito daquilo que é fática e juridicamente possível. Isso significa que a distinção entre regras e princípios é uma distinção qualitativa, e não uma distinção de grau. Toda norma é uma regra ou um princípio."

30 DWORKIN, Ronald. Levando os direitos à sério. São Paulo: M. Fontes, 2002. p. 39.

31 Segundo ele: "A diferença entre princípios jurídicos e regras jurídicas é de natureza lógica. Os dois conjuntos de padrões apontam para decisões particulares acerca da obrigação jurídica em circunstâncias específicas, mas distinguem-se quanto à natureza da orientação que oferecem. As regras são aplicáveis à maneira do tudo-ou-nada. Dados os fatos que uma regra estipula, então ou a regra é válida, e neste caso a resposta que ela fornece deve ser aceita, ou não é válida, e neste caso em nada contribui para a decisão. Um princípio [...] não pretende [nem mesmo] estabelecer condições que tornem sua aplicação necessária. Ao contrário, enuncia uma razão que conduz o argumento em uma certa direção, mas [ainda assim] necessita uma decisão particular. Os princípios possuem uma dimensão que as regras não têm - a dimensão do peso ou importância. Quando os princípios se intercruzam (por exemplo, a política de proteção aos compradores de automóveis se opõe aos princípios de liberdade de contrato), aquele que vai resolver o conflito tem que levar em conta a força relativa de cada um. Esta não pode ser, por certo, uma mensuração exata [...] As regras não têm essa dimensão. Podemos dizer que as regras são funcionalmente importantes ou desimportantes. [...] Neste sentido, uma regra jurídica pode ser mais importante do que outra porque desempenha um papel maior ou mais importante na regulação do comportamento. Mas não podemos dizer que uma regra é mais importante que outra enquanto parte do mesmo sistema de regras, de tal modo que se duas regras estão em conflito, uma suplanta a outra em virtude de sua importância maior. Se duas regras entram em conflito, uma delas não pode ser válida. [...]” 
propriedade possui status de princípio em nosso ordenamento jurídico. Em outra passagem sobre o mesmo tema, Dworkin fornece um conceito de princípio que ratifica o enquadramento da função social como tal: "Denomino "princípio" um padrão que deve ser observado, não porque vá promover ou assegurar uma situação econômica, política ou social considerada desejável, mas porque é uma exigência de justiça ou equidade ou alguma outra dimensão da moralidade."32

As palavras do mestre americano levam a concluir que a função social possui um conteúdo moral, pois, na medida em que o proprietário tem responsabilidade sobre o destino da coisa possuída em relação a coletividade, ele estará, de algum modo, atendendo a um preceito moral, e de equidade, na sociedade da qual faz parte. Nesse sentido, está também a lição de Rocha ${ }^{33}$, que já inicia sua obra partindo do pressuposto de que a função social da propriedade possui a estrutura de princípio.

Afastada eventual dúvida quanto à natureza da função social da propriedade, há que se discutir para quais as espécies de propriedade esse princípio se aplica e de que forma.

\subsection{Aplicação da função social}

Definidas as premissas iniciais de que a função social da propriedade é norma abarcada pelo ordenamento jurídico brasileiro e que se trata de um princípio de direito fundamental, passa-se agora a verificar sua aplicação. Para tanto, separa-se a propriedade privada da propriedade pública para fins de análise.

\subsection{Propriedade privada}

No que tange à aplicação do princípio da função social às propriedades privadas é necessário se considerar em primeiro lugar, o viés social-democrático do Estado Brasileiro, refletido na Constituição de $1988^{34}$. Disso,

32 DWORKIN, Ronald. Levando os direitos à sério. São Paulo: M. Fontes, 2002. p. 35.

33 ROCHA, Silvio Luis Ferreira. Função social da propriedade pública. São Paulo: Malheiros, 2005. p. 09.

34 O Estado Democrático de Direito, princípio estruturante do Estado Brasileiro, está inserto já no artigo primeiro da Constituição de 1988. Segundo Mendes (2008, p. 149) "em que pesem pequenas variações semânticas em torno desse núcleo essencial, entende-se como Estado Democrático de Direito a organização política em que o poder emana do povo, que o exerce diretamente ou por meio de representantes, escolhidos em eleições livres e periódicas, mediante sufrágio universal e voto direto e secreto, para o exercício de mandatos periódicos, como proclama, entre pode-se inferir que a inspiração do Poder Constituinte Originário brasileiro perpassou pelas lições de Leon Duguit, sobretudo na parte que o autor francês ensina que a propriedade tem uma dupla finalidade que é atender às necessidades individuais de seu proprietário sem descurar, contudo, do atendimento das necessidades da coletividade da qual o dono da propriedade faz parte.

Nos casos das propriedades privadas a função social se presta a refrear os impulsos da sociedade que, embora tenha preocupações com aspectos sociais, ainda é uma sociedade capitalista. O princípio em comento parece contribuir na busca pela sociedade equânime, na qual haja, tanto quanto possível, a igualdade substancial.

Na concepção trazida por Dworkin ${ }^{35}$, sobretudo em sua obra $A$ virtude soberana, a igualdade e liberdade são complementares e interdependentes. Desde modo, ao se defender a igualdade estar-se-ia também defendendo a liberdade. Assim, quando se aplica a função social, estão sendo resguardados dois princípios basilares do Estado Democrático de Direito, ou seja, igualdade e liberdade. Os proprietários que cumprem a função social contribuem na construção de uma sociedade mais justa como um todo.

\subsection{Propriedade pública}

Se por um lado é tranquila a visualização da aplicação da função social no âmbito da propriedade privada, o mesmo não ocorre quando se fala nas propriedades públicas. Existe discussão doutrinária sobre a aplicabilidade ou não desse princípio no âmbito público. Contudo, antes de se adentrar a ela, será necessário esclarecer que o presente trabalho foca tão somente nas propriedades públicas imóveis.

Ainda, nessa seara, é imprescindível penetrar, mesmo que de modo não aprofundado, nos tipos de bens públicos, assim como nas suas respectivas finalidades.

Justen Filho $^{36}$ conceitua bens públicos como

outras, a Constituição brasileira. Mais ainda, já agora no plano das relações concretas entre o Poder e o indivíduo, considera-se democrático aquele Estado de Direito que se empenha em assegurar aos seus cidadãos o exercício efetivo não somente dos direitos civis e políticos, mas também e sobretudo dos direitos econômicos, sociais e culturais, sem os quais de nada valeria a solene proclamação daqueles direitos."

35 DWORKIN, Ronald. A virtude soberana: a teoria e prática da igualdade. 2. ed. São Paulo: M. Fontes, 2011.

36 JUSTEN FILHO, Marçal. Curso de direito administrativo. 5. ed. São Paulo: Saraiva, 2010. p. 1044. 
aqueles de titularidade do Estado que são subordinados a regime jurídico de direito público e indispensáveis ao desempenho das funções públicas ou merecedores de proteção especial.

Mello $^{37}$ afirma que o domínio público é formado pelo conjunto dos bens públicos, tanto móveis como imóveis. No mesmo sentido, Cretella Júnior ${ }^{38}$ conceitua domínio público como "o conjunto de bens móveis e imóveis destinados ao uso direto do Poder Público ou à utilização direta ou indireta da coletividade, regulamentados pela Administração e submetidos a regime de direito público."

Há diversas classificações dos bens públicos, dentre as quais pode-se citar: bens públicos móveis e imóveis, bens públicos de domínio público natural e artificial, bens públicos de domínios terrestre, hídrico e aéreo ${ }^{39}$. Porém, aqui interessa, sobretudo, a classificação apresentada a seguir.

A doutrina administrativista divide os bens públicos em três tipos ${ }^{40}$, quais sejam: bens de uso comum, bens de uso especial e bens dominiais ou dominicais. ${ }^{41}$

37 MELLO, Celso Antônio Bandeira de. Curso de direito administrativo. 26. ed. São Paulo: Malheiros, 2009. p. 884.

38 CRETELLA JÚNIOR, José. Dicionário de direito administrativo. Rio de Janeiro: Forense, 1980. p. 204.

39 COUTINHO, José Roberto de Andrade. Gestão patrimonial na Administração Pública: aquisição, alienação ou perda e oneração de bens públicos em espécie, processos de trabalho e modelos de gestão de bens, minutas e modelos de atos, contratos e editais de licitação. Rio de Janeiro: Lúmen Júris, 2005. p. 63-68.

40 Há previsão dos tipos de bens públicos no artigo 99 do código civil, o qual assevera: "Art. 99. São bens públicos: I os de uso comum do povo, tais como rios, mares, estradas, ruas e praças; II - os de uso especial, tais como edifícios ou terrenos destinados a serviço ou estabelecimento da administração federal, estadual, territorial ou municipal, inclusive os de suas autarquias; III - os dominicais, que constituem o patrimônio das pessoas jurídicas de direito público, como objeto de direito pessoal, ou real, de cada uma dessas entidades. Parágrafo único. Não dispondo a lei em contrário, consideram-se dominicais os bens pertencentes às pessoas jurídicas de direito público a que se tenha dado estrutura de direito privado."

41 JUSTEN FILHO, Marçal. Curso de direito administrativo. 5. ed. São Paulo: Saraiva, 2010. p. 1055 faz severa crítica a essa classificação, que apesar de pertinente, não afeta diretamente o escopo deste trabalho. Apesar disso, é interessante conhecê-la. O autor tacha a classificação em comento de ultrapassada e aponta dois grandes problemas: "O primeiro problema reside em que o legislador tinha em mente apenas os bens imóveis, olvidando a existência e relevância dos bens móveis e direitos. Assim, a classificação não contempla, por exemplo, os direitos de propriedade industrial (tais como patentes), que apresentam enorme importância econômica e social. Ademais disso, existe grande relevância jurídica quanto aos direitos
Diferentemente do entendimento de Mello $^{42}$ e Cretella Júnior $^{43}$, Di Pietro ${ }^{44}$ entende que a tripartição dos bens públicos ainda comportaria uma outra divisão. Segundo a autora, os bens de uso comum do povo e os bens de uso especial perfariam o domínio público. Já os bens dominicais integrariam o domínio privado do Estado. ${ }^{45}$

Os bens de uso comum do povo são aqueles que, consoante já se infere do próprio nome, podem ser usufruídos indistintamente por qualquer pessoa do povo, ou seja, destinam-se ao uso geral da coletividade, Carvalho Filho ${ }^{46}$ cita como exemplos desse tipo de bens os mares, os rios, as praias, as estradas, as praças e os logradouros públicos. $^{47}$

Para Justen Filho o critério de identificação desse tipo de bem perfaz-se pela natureza e destinação do

de uso e fruição de bens públicos de natureza imóvel. O grande exemplo disso é o direito de exploração de potenciais hidráulicos de geração energética. A segunda insuficiência da classificação reside na concepção altamente individualista do tratamento reservado aos bens ditos de uso comum. Especialmente a partir de $\mathrm{CF} / 88$, é necessário reconhecer a existência de uma categoria de bens que é de titularidade, mas não de uso, comum do povo. Trata-se do meio ambiente e de outros recursos naturais, cujo uso e fruição podem ser interditados ao povo em geral. É necessário reconhecer, então, a existência de uma outra categoria específica de bens públicos, consistente nos bens públicos comuns protegidos."

42 MELLO, Celso Antônio Bandeira de. Curso de direito administrativo. 26. ed. São Paulo: Malheiros, 2009.

43 CRETELLA JÚNIOR, José. Dicionário de direito administrativo. Rio de Janeiro: Forense, 1980.

44 DI PIETRO, Maria Sylvia Zanella. Direito administrativo. 17. ed. São Paulo: Atlas, 2004. p. 96.

45 LOFUTO, Renan. Código Civil comentado: parte geral: art. 1 a 123. São Paulo: Saraiva, 2003. v. 1. Comunga da mesma ideia de DI PIETRO, Maria Sylvia Zanella. Direito administrativo. 17. ed. São Paulo: Atlas, 2004.

46 CARVALHO FILHO, José dos Santos. Manual de direito administrativo. 19. ed. Rio de Janeiro: Lumen Juris, 2008. p. 1004.

47 JUSTEN FILHO, Marçal. Curso de direito administrativo. 5. ed. São Paulo: Saraiva, 2010. p. 1057 faz interessante ressalva sobre este tipo de bem público quando afirma "é usual tratar como bens de uso comum apenas os imóveis. Mas assim não se passa de modo necessário. Suponha-se uma obra de arte, dotada de grande simbolismo para a Nação, o que justifica a aquisição de seu domínio pelo Estado. Assim ocorrendo, será um bem de uso comum do povo. Todo patrimônio artístico e cultural composto por bens móveis e que não seja aplicado diretamente numa atividade estatal ou na prestação de um serviço público, será enquandrado na categoria da bem de uso comum do povo. O imóvel em que está edificado um museu não é bem de uso comum do povo. Trata-se de um bem de uso especial. Mas a obra de arte que se encontra dentro do prédio é um bem de uso comum do povo." 
mesmo. Esse grupo de bens engloba aqueles cujo uso não pode ou não deve ser objeto de apropriação privada exclusiva de algum ou alguns sujeitos. Por fim, o mesmo autor ressalta:

nem sequer se poderia aludir a algum vínculo de propriedade sobre os bens de uso comum. O Estado é titular desses bens porque nenhum sujeito pode adquirir o domínio sobre ele. Mas não é possível afirmar a existência de uma propriedade estatal já que não cabe ao Estado as faculdades de uso e fruição privativos, excludentes de idêntico benefício em prol de terceiros. ${ }^{48}$

Os bens de uso especial são bens voltados a aparelhar o serviço público, isto é, são aqueles aplicados no desempenho das atividades estatais. Visam à execução de serviços públicos. São imóveis indispensáveis à prestação e funcionamento do serviço administrativo e ao serviço público em geral.

Di Pietro ${ }^{49}$ define bens de uso especial como "todas as coisas, móveis ou imóveis, corpóreas ou incorpóreas, utilizadas pela Administração Pública para realização de suas atividades e consecução de seus fins.”

São exemplos de bens de uso especial edifícios onde se situem repartições públicas. O critério de identificação desse tipo de bem reside na afetação ao atendimento de um interesse público específico. Enquanto os bens estiverem afetados ao atendimento de algum serviço público incidirá sobre eles o regime jurídico dos bens públicos.

O uso e fruição desses bens, em princípio, é da Administração Pública. Contudo, os particulares poderão, sob certas condições e circunstâncias, usá-los. Por exemplo, quando um cidadão se dirige a uma repartição pública em busca de uma certidão.

Por fim, os bens dominiais ou dominicais ${ }^{50}$, classificam-se, por exclusão, como sendo aqueles não afetados diretamente à prestação de um serviço público, nem

48 JUSTEN FILHO, Marçal. Curso de direito administrativo. 5. ed. São Paulo: Saraiva, 2010. p. 1057.

49 DI PIETRO, Maria Sylvia Zanella. Direito administrativo. 17. ed. São Paulo: Atlas, 2004. p. 569.

50 Apesar de a maioria da doutrina dedicada ao Direito Administrativo, dentre os quais cita-se MELLO, Celso Antônio Bandeira de. Curso de direito administrativo. 26. ed. São Paulo: Malheiros, 2009, entender como sinônimos os termos bens dominiais e bens dominicais, CRETELLA JÚNIOR, José. Dicionário de direito administrativo. Rio de Janeiro: Forense, 1980. Diferencia tais denominações nos seguintes termos: bens dominiais como gênero que abarca todos os bens de domínio do Estado e bens dominicais englobando os bens que constituem o patrimônio do Estado, isto é, aqueles que podem ser objeto de direito real ou pessoal. destinados ao uso comum do povo. Sua identificação se dará por eliminação, pois sua noção é residual, ou seja, tudo que não for bem de uso comum, nem bem de uso especial, será bem dominical.

A natureza desses bens leva Cretella Júnior $^{51}$ a afirmar que os três tipos de bens públicos são os únicos que podem gerar renda, constituindo propriamente o patrimônio do Estado.

Consideradas as três categorias apresentadas, com suas respectivas finalidades, passa-se a considerar a eficácia da norma principiológica da função social em cada uma delas.

\section{Eficácia da função social na propriedade pú- blica}

Segundo os ensinamentos de Bobbio ${ }^{52}$, a norma jurídica pode ser valorada de acordo com três critérios independentes: validez, justiça e eficácia. Uma norma jurídica completa seria a válida, justa e eficaz. Leciona o autor:

O problema da justiça é o problema da correspondência ou não da norma aos valores últimos ou finais que inspiram um determinado ordenamento jurídico.[...] norma justa é aquela que deve ser; norma injusta é aquela que não deveria ser. [...] Por isso, o problema da justiça se denomina comumente de problema deontológico do direito.

O problema da validade é o problema da existência da regra enquanto tal, independentemente do juízo de valor sobre ela ser justo ou não. [...] Enquanto para julgar a justiça de uma norma, é preciso compará-la a um valor ideal, para julgar a sua validade é preciso realizar investigações do tipo empírico-racional [...] para decidir se uma norma é válida (isto é como regra jurídica pertencente a um determinado sistema), é necessário com frequência realizar três operações: 1) averiguar se a autoridade de quem ela emanou tinha poder legítimo para emanar normas jurídicas [...] 2) averiguar se não foi ab-rogada [...] 3) Averiguar se não é incompatível com outras normas do sistema, particularmente com uma norma hierarquicamente superior [...] O problema da validade jurídica pressupõe que se tenha respondido à pergunta o que se entende por direito?Trata-se [...] do problema ontológico do direito.

O problema da eficácia de uma norma é o problema de ser ou não seguida pelas pessoas a quem é dirigida. [...] Que uma norma exista

51 CRETELLA JÚNIOR, José. Dicionário de direito administrativo. Rio de Janeiro: Forense, 1980.

52 BOBBIO, Norberto. Teoria da norma jurídica. 4. ed. Rio de Janeiro: Forense, 2006. p. 46. 
como norma jurídica não implica que seja também constantemente seguida. [...] A investigação para averiguar a eficácia ou a ineficácia de uma norma é de caráter histórico-sociológico, se volta para o estudo do comportamento dos membros de um determinado grupo social [...] o problema da eficácia das regras jurídicas é o problema fenomenológico do direito.

Tomando por base a diferenciação proposta por Bobbio $^{53}$, pode-se concluir que a norma principiológica da função social atende de modo pleno aos dois critérios inicialmente apresentados, validade e justiça, no que tange a sua aplicação à propriedade pública.

É norma justa, já que foi inserida num país que adota como modelo de Estado o Estado Democrático de Direito, com claro viés social, no seio de uma Constituição, prolixa e dirigente, para dizer o mínimo. Assim, evidencia-se a correspondência da função social da propriedade com os valores últimos que inspiraram o ordenamento jurídico brasileiro. Tanto no caso de considerar que existem valores supremos evidentes, quanto no caso de não se acreditar na existência de tais valores, a norma também será apta a realizar os valores históricos que inspiraram o ordenamento pátrio.

É norma válida, pois, é norma existente no ordenamento jurídico e passa no teste empírico-racional na medida em que atende aos três requisitos trazidos por Bobbio $^{54}$ : 1- foi aprovada por autoridade competente e com poder legítimo para emanar normas jurídicas, Assembleia Nacional Constituinte responsável pela confecção da Constituição de $1988^{55}$; 2 - Não foi ab-rogada, não houve norma posterior que lhe contrariasse o sentido; e 3- Não é incompatível com o sistema no qual se insere, até mesmo porque está topograficamente localizada na norma de maior hierarquia dentro do ordenamento que integra $^{56}$.

Quanto ao último critério previsto por Bobbio ${ }^{57}$,

53 BOBBIO, Norberto. Teoria da norma jurídica. 4. ed. Rio de Janeiro: Forense, 2006.

54 BOBBIO, Norberto. Teoria da norma jurídica. 4. ed. Rio de Janeiro: Forense, 2006

55 Exceto no art.173, $\$ 1^{\circ}$, I da CF/88 que fala de função social, posto que neste caso foi obra do Poder Constituinte Derivado por tratar-se de inserção feita pela EC no 19 de 1998. Contudo, no que se refere a função social voltada para a propriedade, todos os pontos nos quais é citada na CF/88 são obra do Poder Constituinte Originário.

56 Apesar de aparecer também em outras normas, como por exemplo no código civil, no estatuto das cidades, Lei $10257 / 2001$, etc. porém, podem restar alguns questionamentos sobre o preenchimento dos requisitos pela norma da função social da propriedade. Isso se dá, sobretudo, em relação à eficácia da função social da propriedade nas propriedades imóveis públicas. Será ela eficaz nesse ponto específico?

Tendo em conta o problema terminológico das várias acepções do termo eficácia, questão que vai muito além do presente estudo, partir-se-á dos estudos de Bobbio $^{58}$ para definir o sentido de eficácia que aqui se busca:

O problema da eficácia nos leva ao terreno da aplicação da normas jurídicas, que é o terreno dos comportamentos efetivos dos homens que vivem em sociedade, dos interesses contrastantes, das ações e reações frente à autoridade, dando lugar às investigações em torno da vida do direito, na sua origem, no seu desenvolvimento, na sua modificação, investigações estas que normalmente são conexas a indagações de caráter histórico e sociológico. Daí nasce aquele aspecto da filosofia do direito que conflui para a sociologia jurídica.

Ainda na busca do significado de eficácia, é indispensável a lição de Silva. O autor divide a eficácia em duas: eficácia social e eficácia jurídica, e segue sua lição demonstrando as características de cada uma:

II Eficácia do Direito. Toma-se a expressão em dois sentidos. A eficácia social designa uma efetiva conduta acorde com a prevista pela norma; refere-se ao fato de que a norma é realmente obedecida e aplicada; nesse sentido, a eficácia da norma diz respeito, como diz Kelsen ao 'fato real de que ela é efetivamente aplicada e seguida, da circunstância de uma conduta humana conforme a norma se verificar na ordem dos fatos.' A eficácia jurídica da norma designa a qualidade de produzir, em maior ou menor grau, efeitos jurídicos, ao regular, desde logo, as situações, relações e comportamentos nela indicados; nesse sentido, a eficácia diz repeito à aplicabilidade, exigibilidade ou executoriedade da norma, como possibilidade de sua aplicação jurídica. Possibilidade e não efetividade. ${ }^{59}$

Sarlet ${ }^{60}$ compartilha dos ensinamentos de Silva na divisão da eficácia. Os dois sentidos de eficácia trazidos por Silva $^{61}$ são conexos. No presente estudo, entretanto, a intenção é investigar a segunda modalidade de eficácia, isto é a eficácia jurídica da função social em relação à pro-

58 BOBBIO, Norberto. Teoria da norma jurídica. 4. ed. Rio de Janeiro: Forense, 2006.p. 51.

59 SILVA, José Afonso da. Aplicabilidade das normas constitucionais. São Paulo: Revista dos Tribunais, 1968. p. 58.

60 SARLET, Ingo Wolfgang. A eficácia dos direitos fundamentais. 12. ed. Porto Alegre: Livraria do Advogado, 2015. p. 245.

61 SILVA, José Afonso da. Aplicabilidade das normas constitucionais. São Paulo: Revista dos Tribunais, 1968. 
priedade pública.

Diante disso, deve-se ter em conta a possibilidade de aplicação da norma da função social quando se tratar de imóveis públicos. A doutrina diverge bastante sobre tal ponto.

Uma primeira corrente entende inaplicável a norma da função social à propriedade pública, negando-lhe assim eficácia. $\mathrm{O}$ fundamento dos que se filiam a esse grupo remonta aos fins próprios dos imóveis públicos. Alegam que os bens públicos já estariam voltados para atender à coletividade por sua própria natureza e por isso não faria sentido falar-se em função social desses bens. Asseveram que a função social do modo como está cunhada na Constituição aplicar-se-ia tão somente aos bens privados. Partidária dessa corrente, Abe nota:

que, enquanto dever fundamental, a função social da propriedade, previsto no art. 5. ${ }^{\circ}$, XXIII, da Constituição Federal, deve ser atendida por todos os particulares e, não pelo Estado, pois as sanções jurídicas previstas para o descumprimento da função social da propriedade urbana são imputáveis apenas aos particulares, sendo inadequadas para punir os entes públicos (União, Estados, DF, Municípios) pelo descumprimento deste dever. [...]

No meio rural, é patente a inaplicabilidade das sanções jurídicas previstas para o descumprimento da função social aos entes públicos. ${ }^{62}$

Jambrenghi apud Di Pietro ${ }^{63}$ afirma que os bens públicos não cumprem função social porque são eles próprios a função social, isto é, a propriedade pública é a própria função social, assim não tem função social.

Contrariamente, uma segunda corrente entende que é possível a aplicação da função social à propriedade pública, mesmo que não de modo exauriente em todos os casos. Segundo tal linha de pensamento, o fato de o poder público afetar seus bens a fins ligados ao interesse coletivo não exclui a aplicação da função social da propriedade a ele.

Rocha assevera:

Para nós, a finalidade cogente informadora do domínio público não resulta na imunização dos efeitos emanados do princípio da função social da propriedade, previsto no texto constitucional. Acreditamos que a função social da propriedade é princípio constitucional que incide sobre

62 ABE, Nilma de Castro. Notas sobre a inaplicabilidade da função social à propriedade pública. Revista Brasileira de Direito Constitucional, São Paulo, n. 11, p. 135-154, jan./ jun. 2008. p.142.

63 DI PIETRO, Maria Sylvia Zanella. A gestão do patrimônio imobiliário do Poder Público. Cadernos FUNDAP, São Paulo, ano 9, n. 17, p. 55-66, dez. 1989. toda e qualquer relação jurídica de domínio, pública ou privada, não obstante reconheçamos ter havido um desenvolvimento maior dos efeitos do princípio da função social no âmbito do instituto da propriedade privada, justamente em razão do fato de o domínio público, desde a sua existência, e, agora, com maior intensidade, estar, de um modo ou de outro, voltado sempre ao cumprimento de fins sociais, pois, como visto, marcado pelo fim de permitir à coletvidade o gozo de certas utilidades. ${ }^{64}$

Ainda na análise da eficácia do princípio da função social em sua aplicação nas propriedades públicas, é necessário que se considere separadamente cada uma das espécies de bens públicos analisadas no item anterior, isto é, bens de uso comum, bens de uso especial e bens dominiais.

As três categorias de bens públicos são igualmente vocacionadas ao atendimento das necessidades da coletividade de modos diferentes. Todos, dentro da ótica constitucional brasileira, devem ser meios de o Estado promover e assegurar os direitos fundamentais. Justen Filho afirma que:

Os bens públicos são essencialmente um conjunto de instrumentos para que o Estado desempenhe os seus deveres. Consolida-se, então, a concepção de que os bens públicos são um instrumento para a promoção dos direitos fundamentais. Os bens públicos devem ser utilizados, de modo direto, para assegurar a toda a comunidade a obtenção das necessidades essenciais à sua dignidade. Será obrigatória a aplicação do bem público sempre que sua utilização configurar-se como o meio adequado para satisfazer direitos fundamentais. ${ }^{65}$

Rocha reitera a importância da classificação dos bens públicos para o estudo da função social nos seguintes termos:

Acreditamos ser útil a classificação dos bens em uso comum, uso especial e dominical por estabelecer diversidade de regimes jurídicos que resultam em modos distintos de incidência e aplicação do princípio da função social da propriedade aos bens públicos, embora não neguemos a possibilidade da incidência do princípio da função social a todas as categorias de bens públicos. $^{66}$

Mesmo os bens públicos de uso especial e de uso comum do povo, pertencentes à categoria do domínio

${ }^{64}$ ROCHA, Silvio Luis Ferreira. Função social da propriedade pública. São Paulo: Malheiros, 2005. p. 127.

65 JUSTEN FILHO, Marçal. Curso de direito administrativo. 5. ed. São Paulo: Saraiva, 2010. p. 1047.

66 ROCHA, Silvio Luis Ferreira. Função social da propriedade pública. São Paulo: Malheiros, 2005. p. 127. 
público do Estado, afetados ao uso da administração e ao uso coletivo, respectivamente, poderiam, na perspectiva de Justen Filho ${ }^{67}$ e Rocha ${ }^{68}$, ser submetidos à função social com intuito de dar a maior aplicabilidade possível aos direitos fundamentais, desde que não haja nenhum prejuízo para a afetação a que se destinam primordialmente.

Já no que se refere aos bens dominicais, pertencentes ao domínio privado do Estado, por suas características já definidas anteriormente, fica mais clara a possibilidade de aplicação da função social da propriedade, assim como sua maior incidência. A proximidade que os bens dominiais têm com o regime dispensado aos bens particulares, considerando que não possuem afetação, faz com que a função social incida sobre os mesmos de modo bastante semelhante ao que ocorre aos bens particulares.

Di Pietro comunga das mesmas ideias como se percebe da afirmação a seguir:

Com relação aos bens de uso comum do povo e bens de uso especial, afetados, respectivamente, ao uso coletivo e ao uso da própria Administração, a função social exige que ao uso principal a que se destina o bem sejam acrescentados outros usos, sejam públicos ou privados, desde que não prejudiquem a finalidade a que o bem está afetado. Com relação aos bens dominicais, a função social impõe ao poder público o dever de garantir a sua utilização por forma que atenda às exigências fundamentais de ordenação da cidade expressas no plano diretor, dentro dos objetivos que a Constituição estabelece para a política de desenvolvimento urbano. ${ }^{69}$

As escolhas feitas pelo Estado Brasileiro, materializadas na Carta Política em vigor, indicam que o posicionamento que melhor se amolda à questão é a aplicação da função social às propriedades públicas, na medida do possível para os bens de uso especial e de uso comum, devido à sua afetação e na maior medida possível aos bens dominicais.

Desta feita, após análise de todos os pontos supramencionados, a eficácia da função social em relação às propriedades públicas resta patente, pois se demonstrou que se trata de norma de direito fundamental inserta no art. $5^{\circ}$ da Constituição brasileira, e portanto, deve ser

67 JUSTEN FILHO, Marçal. Curso de direito administrativo. 5. ed. São Paulo: Saraiva, 2010.

68 ROCHA, Silvio Luis Ferreira. Função social da propriedade pública. São Paulo: Malheiros, 2005.

69 DI PIETRO, Maria Sylvia Zanella. Função social da propriedade pública. Revista Eletrônica de Direito do Estado, Salvador, n. 6, p. 1-13, abr./jun. 2006. Disponível em: $<$ http://www.direitodoestado.com.br/>. Acesso em: 23 dez. 2015. aplicada na maior amplitude possível, inclusive quando se tratar de propriedades públicas. Ademais, conforme já dito, essa é a posição que melhor se coaduna com o modelo de Estado adotado no Brasil.

A eficácia da função social da propriedade pública é confirmada por outros normativos infraconstitucionais, tais como a Lei 11977/09 que prevê regularização fundiária de interesse social, inclusive em áreas públicas ${ }^{70}$; a Lei 11952/09 que trata da regularização fundiária em terras da União no âmbito da Amazônia Legal; assim como os instrumentos jurídicos de regularização da concessão de uso de bem público, da concessão de direito real de uso ${ }^{71}$ e da concessão de uso especial para moradia ${ }^{72}$.

Todos esses instrumentos corroboram a tese de que a função social é aplicável aos imóveis públicos. Apesar de ser certo que a maioria deles se amolda melhor aos bens dominicais, a função social também deverá ser perseguida, na medida do possível, nos demais bens públicos.

Vem a calhar as palavras de Melo quando afirma no contexto da viabilização da moradia e da regularização fundiária que

A constituição positiva uma série de valores como normas, resultado da opção do constituinte por um modelo de Estado caracterizado pela submissão das funções estatais a princípios de conteúdo social, bem como à participação popular e a um modelo político republicano que traça sua geografia deixando em relevo o princípio de igualdade formal e material, tendo a sociedade como fundamento e fim. ${ }^{73}$

Os entendimentos plasmados na Constituição, assim como seus fins, corroboram que a função social da propriedade deve ter a aplicabilidade mais ampla possível, o que por certo inclui os bens públicos na medida de suas especificidades.

70 Lei no $11977 / 09$ _ Art. 47. Para efeitos da regularização fundiária de assentamentos urbanos, consideram-se: [...] VII - regularização fundiária de interesse social: regularização fundiária de assentamentos irregulares ocupados, predominantemente, por população de baixa renda, nos casos: a) em que a área esteja ocupada, de forma mansa e pacífica, há, pelo menos, 5 (cinco) anos; b) de imóveis situados em ZEIS; ou c) de áreas da União, dos Estados, do Distrito Federal e dos Municípios declaradas de interesse para implantação de projetos de regularização fundiária de interesse social; (grifo nosso)

$71 \quad$ Art. $7^{\circ}$ do Decreto-lei no $271 / 67$

72 Lei 10257/01- Estatuto da cidade e Lei 9636/98.

73 MELO, Lígia. Direito à moradia no Brasil: política urbana e acesso por meio da regularização fundiária. Belo Horizonte: Fórum, 2010. p. 113. 


\section{Conclusão}

Após a análise dos pontos discutidos no presente escrito, conclui-se, em primeiro lugar, que resta evidente o viés social adotado pela atual carta política brasileira. Assim como é possível identificar a inserção da função social de modo mais amplo que as constituições anteriores confirmando tal viés social da Constituição de 1988.

É imperativo frisar que a nova alocação, dentro dos direitos e garantias fundamentais, faz com que a aplicação da função social da propriedade deva ser a mais ampla possível.

A análise da função social leva a certeza de que se trata de um princípio de direito fundamental e que por isso deve ser aplicado do modo mais dilatado, pois não será excluído em caso de conflito com outros princípios, mas sim terá sua aplicação ponderada, sopesada para harmonização do sistema constitucional.

Ainda nessa seara, restou clara a imperiosa aplicação do princípio às propriedades privadas em razão do modelo de Estado adotado pelo Brasil que, em apertada síntese, prima pela busca da igualdade material entre seus cidadãos.

Contudo, a princípio, poderiam restar dúvidas sobre a aplicação da função social às propriedades públicas. Questionada sua eficácia quanto a esse tipo de propriedade, pareceu, inicialmente, que a finalidade dos bens imóveis públicos, já voltada ao atendimento dos interesses coletivos, poderia, em certa medida, impedir a aplicação da função social a elas.

Todavia, quando se pensa em cada um dos tipos de propriedade, é possível vislumbrar a possibilidade de aplicação da função social no âmbito público, notadamente quando se trata de bens dominicais.

O emprego da função social aos bens dominicais pode ser comprovado, por exemplo, na criação da Concessão de Direito Real de Uso e outros instrumentos de teor semelhante, que atendem à função social da propriedade pública dominial, em termos parecidos ao que faria em relação a uma propriedade privada.

Conclui-se ser aplicável e eficaz o princípio da função social da propriedade em relação aos imóveis públicos, mesmo que, em alguns casos, de modo menos amplo que em relação à propriedade privada.

Com a adoção da visão esposada por este trabalho dar-se-á a mais plena concretude aos ditames constitu- cionais, privilegiando a igualdade material entre os indivíduos, o que contribui na busca pela igualdade material entre os indivíduos.

\section{Referências}

ABE, Nilma de Castro. Notas sobre a inaplicabilidade da função social à propriedade pública. Revista Brasileira de Direito Constitucional, São Paulo, n. 11, p. 135-154, jan./ jun. 2008.

ALEXY, Robert. Teoria dos direitos fundamentais. 2. ed. São Paulo: Malheiros, 2014.

BOBBIO, Norberto. Teoria da norma jurídica. 4. ed. Rio de Janeiro: Forense, 2006.

BONAVIDES, Paulo. Curso de direito constitucional. 25. ed. São Paulo: Malheiros, 2010.

BRASIL. Constituição (1934). Constituição da República dos Estados Unidos do Brasil. Disponível em: <http:// www.planalto.gov.br/ccivil_03/constituicao/constituicao34.htm>. Acesso em: 17 set. 2016.

BRASIL. Emenda constitucional $n$. 1, de 17 de outubro de 1969. Disponível em: <http://www.planalto.gov.br/ccivil_03/Constituicao/Emendas/Emc_anterior1988/emc0169.htm>. Acesso em: 17 set. 2016.

BRASIL. Constituição (1988). Constituição da República Federativa do Brasil. Disponível em: <http://www.planalto.gov.br/ccivil_03/Constituicao/Constituicao.htm>. Acesso em: 17 set. 2016.

BRASIL. Lei n. 11.977, de 7 de julho de 2009. Disponível em: <http://www.planalto.gov.br/ccivil_03/_ato20072010/2009/lei/111977.htm>. Acesso em: 17 set. 2016.

BRASIL. Decreto-Lei n. 271, de 28 de fevereiro de 1967. Disponível em: <http://www.planalto.gov.br/ccivil_03/ decreto-lei/Del0271.htm>. Acesso em: 17 set. 2016.

BRASIL. Lei n. 10.257, de 10 de julho de 2001. Disponível em: <http://www.planalto.gov.br/ccivil_03/leis/ LEIS_2001/L10257.htm>. Acesso em: 17 set. 2016.

BRASIL. Lei n. 9.636, de 15 de maio de 1998. Disponível em: <http://www.planalto.gov.br/ccivil_03/leis/ LEIS_1998/L9636.htm>. Acesso em: 17 set. 2016.

CARVALHO FILHO, José dos Santos. Manual de direito administrativo. 19. ed. Rio de Janeiro: Lumen Juris, 2008.

CENCI, Ana Righi; BENDIN, Gabriel de Lima; FISCHER, Ricardo Santi. Do liberalismo ao intervencionismo: 
o estado como protagonista da (des)regulação econômica. Constituição, Economia e Desenvolvimento: Revista da Academia Brasileira de Direito Constitucional, Curitiba, n. 4, p. 77-97, jan./jun., 2011.

CRETELLA JÚNIOR, José. Dicionário de direito administrativo. Rio de Janeiro: Forense, 1980.

DI PIETRO, Maria Sylvia Zanella. Direito administrativo. 17. ed. São Paulo: Atlas, 2004.

DI PIETRO, Maria Sylvia Zanella. A gestão do patrimônio imobiliário do Poder Público. Cadernos FUNDAP, São Paulo, ano 9, n. 17, p. 55-66, dez. 1989.

DI PIETRO, Maria Sylvia Zanella. Função social da propriedade pública. Revista Eletrônica de Direito do Estado, Salvador, n. 6, p. 1-13, abr./jun., 2006. Disponível em: $<$ http://www.direitodoestado.com.br/>. Acesso em: 23 dez. 2015.

DUGUIT, Leon. Les transformations générales du droit privé depuis le code Napoléon. 19. ed. Paris: Librairie Félix Alcan, 1920.

DWORKIN, Ronald. A virtude soberana: a teoria e prática da igualdade. 2. ed. São Paulo: M. Fontes, 2011.

DWORKIN, Ronald. Levando os direitos à sério. São Paulo: M. Fontes, 2002.

HERRERA, Carlos Miguel. Estado, constituição e direitos sociais. Revista da Faculdade de Direito da Universidade de São Paulo, São Paulo, v. 102, p. 371-395 jan./dez., 2007.

JUSTEN FILHO, Marçal. Curso de direito administrativo. 5. ed. São Paulo: Saraiva, 2010.

LÔBO, Paulo Luiz Netto. Constitucionalização do direito civil. In: FIUZA, César; NAVES, Bruno Torquato de Oliveira; SÁ, Maria de Fátima Freire de; (Coord.). Direito civil: atualidades II. Belo Horizonte: Del Rey, 2003. p. 197-217.

LOFUTO, Renan. Código Civil comentado: parte geral (art. 1º 123). Saraiva: São Paulo, 2003. v. 1.
MELO, Lígia. Direito à moradia no Brasil: política urbana e acesso por meio da regularização fundiária. Belo Horizonte: Forum, 2010.

MELlO, Celso Antônio Bandeira de. Curso de direito administrativo. 26. ed. São Paulo: Malheiros, 2009.

MENDES, Gilma Ferreira; COELHO, Inocêncio Mártires; BRANCO, Paulo Gustavo Gonet. Curso de direito constitucional. 2. ed. São Paulo: Saraiva, 2008.

MENEZES, Olindo Herculano de. Perfil da propriedade contemporânea destaque da propriedade fundiária. 2009. Tese. (Doutorado) - Universidade de Brasília, Brasília, 2009. Disponível em: <http://repositorio.unb.br/bitstream/10482/4076/1/2009_OlindoHerculanodeMenezes.pdf $>$. Acesso em: 20 jan. 2016.

ROCHA, Silvio Luis Ferreira. Função social da propriedade pública. São Paulo: Malheiros, 2005.

ROUSSEAU, Jean- Jacques, 1712-1778. Do contrato social: princípios de direito político. 2. ed. São Paulo: Revista dos Tribunais, 2008.

SANTOS, Sérgio Roberto Leal dos. Três momentos do Estado de Direito. Jus Navigandi, Teresina, ano 15, n. 2524, (on line), 30 maio 2010. Disponível em: <https://jus.com. br/artigos/14935/tres-momentos-do-estado-de-direito $>$. Acesso em: 17 dez. 2015.

SARLET, Ingo Wolfgang. A eficácia dos direitos fundamentais. 12. ed. Porto Alegre: Livraria do Advogado, 2015.

SILVA, José Afonso da. Aplicabilidade das normas constitucionais. São Paulo: Revista dos Tribunais, 1968.

STRECK, Lenio Luiz; MORAIS, José Luis Bolzan de. Ciência política e teoria do Estado. 7. ed. Porto Alegre: Livraria do Advogado, 2010. 